\title{
A revision of the status of Lepadogaster lepadogaster (Teleostei: Gobiesocidae): sympatric subspecies or a long misunderstood blend of species?
}

\author{
MIGUEL HENRIQUES ${ }^{1,2 *}$, RITA LOURENÇO ${ }^{2}$, FREDERICO ALMADA ${ }^{2}$, GONÇALO \\ CALADO $^{2,3}$, DAVID GONÇALVES ${ }^{2}$, THOMAS GUILLEMAUD ${ }^{4,5}$, M. LEONOR CANCELA ${ }^{5}$ \\ and VÍTOR C. ALMADA ${ }^{2}$ \\ ${ }^{1}$ Parque Natural da Arrábida, Instituto da Conservação da Natureza, Praça da República, 2900 \\ Setúbal, Portugal \\ ${ }^{2}$ Unidade de Investigação em Eco-Etologia, Instituto Superior de Psicologia Aplicada, R. Jardim do \\ Tabaco 34, 1149-041 Lisboa, Portugal \\ ${ }^{3}$ Laboratorio de Zooloxía Mariña. Departamento de Bioloxía Animal, Universidade de Santiago de \\ Compostela. 157082 Santiago de Compostela. Spain \\ ${ }^{4}$ USVE, INRA, BP 078, 06606 Antibes cedex, France \\ ${ }^{5}$ Centre for Marine Sciences, CCMAR, University of Algarve, Campus de Gambelas, 8000-810 Faro, \\ Portugal
}

\begin{abstract}
Molecular (partial mitochondrial 12S ribosomal DNA sequences), morphological and meristic analysis of Lepadogaster lepadogaster lepadogaster, L. l. purpurea and L. zebrina were performed to investigate the relationships between these taxa. On the western shore of mainland Portugal, where the two subspecies of L. lepadogaster occur sympatrically, they differ in microhabitat preferences and their breeding seasons are largely out of phase. This information, combined with data on distribution patterns, led to the following conclusions: Lepadogaster l. purpurea is considered to be a valid species, L. purpurea (Bonnaterre, 1788), different from L. l. lepadogaster, now designated L. lepadogaster (Bonnaterre, 1788). L. zebrina was found to be a synonym of L. lepadogaster. The two newly defined species were found to be in sympatry at Madeira and the Canary islands, the Atlantic coast of the Iberian Peninsula, and the Mediterranean at least as far as Genoa (Italy). Diagnostic characters and a list of synonyms are provided. (c) 2002 The Linnean Society of London, Biological Journal of the Linnean Society, 2002, 76, 327-338.
\end{abstract}

ADDITIONAL KEYWORDS: breeding season - Lepadogaster purpurea - L. zebrina - Mediterranean microhabitat segregation - morphometry - north-eastern Atlantic - species revalidation - 12S rDNA.

\section{INTRODUCTION}

As defined by Briggs (1955) the genus Lepadogaster includes three species: $L$. candollei Risso (1810), $L$. lepadogaster (Bonnaterre, 1788) and L. zebrina Lowe (1839). Two subspecies of $L$. lepadogaster were recognized. According to Briggs's (1986; 1990) recent revisions, $L$. l. lepadogaster occurs in the Mediter-

*Correspondence. E-mail: pnarr.henriquesf@icn.pt Tel.: + 351 21 2189791, Fax: + 351265541155 ranean from Monaco eastwards as far as Israel and in the Black Sea, and L. l. purpurea in the north-eastern Atlantic from Scotland to Senegal including Madeira and the Canary islands, and in the western Mediterranean eastward to Cape Roux (southern France). L. zebrina has a very restricted distribution limited to Madeira and the Canary Islands while L. candollei is the most widespread species, being present in the Atlantic coasts from England to Senegal, in Madeira and the Canary Islands and throughout the Mediterranean.

Prior to Briggs (1955), the specimens included by this author in L. lepadogaster had been classified in 
very diverse ways by different authors: from only one designation like L. gouanii (e.g. Günther, 1861; Le Danois, 1913) or L. lepadogaster (Fowler, 1936), to as many as four (e.g. Risso, 1826; Ninni, 1933). This confusing situation was due to the fact that many authors proposed the recognition of new species based on small differences of colour patterns and morphology of very limited numbers of specimens, often collected in restricted areas. It is interesting to note that the authors working with British populations consistently recognized the presence of a single form and all pointed to the same set of diagnostic features. On the contrary, in the Mediterranean, several authors (e.g. Risso, 1810, 1826; Canestrini, 1864; Ninni, 1933) expressed the view that at least two distinct entities should be recognized due to the sympatric occurrence of specimens with discordant traits.

On the shores of the Iberian Peninsula, apart from L. candollei, a single species of Lepadogaster was recognized, although with different designations: $L$. gouanii (Albuquerque, 1954-56) or L. lepadogaster (Lozano y Rey, 1960). Both authors, however, felt the need to describe two distinct patterns of body and head colouration. After the work of Briggs (1986), L. $l$. purpurea replaced the older names for the Iberian populations.

Albuquerque (1954-56) considered L. zebrina as a synonym of $L$. gouanii, which implied that the populations of Madeira and mainland Portugal belonged to the same species. However the revision of Briggs (1955) and all subsequent works considered L. zebrina a valid species for Madeira. Brito (1982) confirmed the presence of $L$. zebrina in the Canary Islands.

In a recent revision of the subfamily Lepadogastrinae, Hofrichter (1995) considered L. zebrina a valid species, but noted that its distinction from $L$. l. lepadogaster is rather tenuous. Regarding the two subspecies of $L$. lepadogaster this author noted that their morphological characters largely overlap, and raised doubts on their subspecific status.

During preliminary observations, we noted that two distinct forms of $L$. lepadogaster were consistently found in the coast of mainland Portugal for several years, often in the same localities. Subsequently, it was also found that this overlap extends over hundreds of kilometres, from the entrance of the Gulf of Biscay, southwards at least to the mouth of the Sado River (central west coast of Portugal). The classification of the two forms using the criteria of Briggs (1955) would lead us to recognize the occurrence of the two subspecies of L. lepadogaster in Portugal and northwest Spain. Their extensive overlap and the finding that these two forms differ markedly in their breeding seasons (see Results), led us to consider the hypothesis that we could be in the presence of two different species instead of two subspecies.
In this paper, we re-examine the status of the forms of Lepadogaster previously classified as L. l. lepadogaster and L. l. purpurea and that of L. zebrina, which is very similar. This study combines DNA sequence data with morphological and ecological information and covers material from the Atlantic coast of the Iberian Peninsula, the Mediterranean and the Madeira island.

\section{METHODS}

As the status of the specimens studied in this work is in question, they will be designated in the Methods and Results sections as:

Group 1: Material that would be classified as $L$. $l$. purpurea according to Briggs (1986), including specimens from north-west Spain, west Portugal, Madeira island and the Mediterranean (Genoa, Italy);

Group 2: Material that would be classified as $L$. $l$. lepadogaster but collected far from the distributional area proposed by Briggs $(1957,1986)$ for this subspecies and well inside the distributional area of the purpurea subspecies. Specimens from north-west Spain, western Portugal and western Mediterranean (Malaga, southern Spain);

Group 3: Material that would be classified as the previous group but from the distribution area defined by Briggs $(1957,1986)$ in the Mediterranean for $L . l$. lepadogaster: southern France, Genoa (Italy) and Albania;

Group 4: Fish from Madeira island that would be classified as L. zebrina.

\section{SOURCES OF MATERIAL}

The specimens used for genetic and morphological analysis, their sites of origin and institutions of deposit are listed in Table 1.

\section{MORPHOMETRIC AND MERISTIC ANALYSIS}

Measurements were made under a stereomicroscope with the help of a calliper to a precision of $0.05 \mathrm{~mm}$. To avoid the effects of possible allometric growth the raw data were replaced by their residuals after log-log regression between each measure and standard length (SL). The measurements follow Briggs (1955) with some additions. The morphometric and meristic variables used in this study are presented in Table 2. For all collected specimens body colouration pattern and shape of the head ocelli were recorded.

The presence and distribution of cephalic pores were checked, but they proved to be identical among all fish groups, and thus devoided of phylogenetic information. The number and relative position of those pores 
Table 1. Specimens used in each analysis ( $\mathrm{B}=$ biometric measures; $\mathrm{M}=$ meristic counts; and $\mathrm{G}=$ genetic analysis); sites of origin: Alpertuche, Continental Portugal ( $\left.38^{\circ} 28^{\prime} \mathrm{N} 8^{\circ} 59^{\prime} \mathrm{W}\right)$, Burela, Galiza, NW Spain $\left(43^{\circ} 39^{\prime} \mathrm{N} 7^{\circ} 21^{\prime} \mathrm{W}\right)$, Varigotti, Genoa, Italy $\left(44^{\circ} 11^{\prime} \mathrm{N} 8^{\circ} 24^{\prime} \mathrm{E}\right)$, Funchal, Madeira $\left(32^{\circ} 38^{\prime} \mathrm{N} 16^{\circ} 54^{\prime} \mathrm{W}\right)$, Albania (exact location unknown) and Malaga, Spain $\left(36^{\circ} 43 \mathrm{~N} 4^{\circ} 25^{\prime} \mathrm{W}\right)$; and the institutions of deposit: MO-PNA (Oceanographic Museum of Arrábida Nature Park), MMF (Museu Municipal do Funchal) and HM (Hamburg Museum). For the group/species definitions, see Methods

\begin{tabular}{lllll}
\hline Analysis & No. specimens & Group/species & Origin & Deposit \\
\hline B/M/G & $15 / 15 / 3$ & 1 & Continental Portugal & MO-PNA \\
B/M/G & $12 / 18 / 4$ & 2 & Continental Portugal & MO-PNA \\
B/M/G & $8 / 9 / 2$ & 2 & NW-Spain & MO-PNA \\
M/G & 2 & 1 & NW-Spain & MO-PNA \\
B/M/G & $9 / 9 / 1$ & 3 & Italy & MO-PNA \\
B/M/G & 1 & 1 & Italy & MO-PNA \\
B/M/G & $12 / 13 / 3$ & 4 & Madeira & MO-PNA \\
B/M/G & 1 & 1 & Madeira & MMF \\
B/M & 1 & 3 & Albania & S Spain \\
B/M & 1 & 2 & Albania & MMF \\
B/M & 3 & C. candollei & MO-PNA \\
G & 2 & L. candollei & & \\
\hline
\end{tabular}

were in agreement with the early description of Guitel (1888) for L. gouanii.

To analyse the relationships between the four groups, a discriminant analysis that included their closest relative $L$. candollei was performed. Cluster analysis on morphometric and meristic data was performed using each individual as an OTU based on their euclidian distances and unweighted pair-group average method (UPGMA). Phylogenetic analysis of morphological data was performed with the program 'CONTML' of the software package PHYLIP (Felsenstein, 1989), using a maximum likelihood method with $L$. candollei as an outgroup.

\section{GENETIC ANALYSIS}

Total genomic DNA was extracted from muscle tissue using a proteinase K/SDS based extraction buffer, purified by phenol/chloroform and ethanol precipitation (Maniatis et al., 1982).

Polymerase chain reaction (PCR) was used to amplify a segment of 433 base pairs from the third domain of the $12 \mathrm{~S}$ rDNA. Primers were designed from highly conserved areas of the $12 \mathrm{~S}$ rDNA sequences of six different fish families (accession numbers AF023183, AF023188, AF038484, NC001606, M91245, NC001717, NC001960, AB000667, X99772, Z21921). Primer sequences are 12SFor 5'-AACTGGGATTAGA TACCCCA-3' and 12SRev 5'-GGGAGAGTGACGG GCGGTGTG- $3^{\prime}$ and correspond to regions of $100 \%$ homology between aligned sequences. The positions from $5^{\prime}$ to $3^{\prime}$ of both primers correspond to positions 421-441 and 923-903, respectively, of the human $12 \mathrm{~S}$ rDNA (see Horai et al., 1995).
Amplifications were obtained in a total volume of $20 \mu \mathrm{L}$ with $1.5 \mu \mathrm{M} \mathrm{MgCl} 2,200 \mu \mathrm{M}$ each dNTP, $0.5 \mu \mathrm{M}$ each primer, $0.5 \mathrm{U}$ of Taq polymerase (Gibco BRL, Life Technologies Inc., Gaithersburg, MD, USA), $\approx 20 \mathrm{ng}$ of genomic DNA and $2 \mu \mathrm{L}$ of buffer supplied by the manufacturer. PCR was performed in a Biometra thermocycler (Biometra, Trio-Thermblock, Göttingen, Germany) and the amplifications consisted in $4 \mathrm{~min}$ at $94^{\circ} \mathrm{C}, 30$ cycles of $1 \mathrm{~min}$ at $94^{\circ} \mathrm{C}, 1$ minute at $55^{\circ} \mathrm{C}$, $1 \mathrm{~min}$ at $72^{\circ} \mathrm{C}$ and a final extension period of $10 \mathrm{~min}$ at $72^{\circ} \mathrm{C}$. Each PCR product was purified from the gel and cloned into the pGEM-T easy vector following the recommendations of the manufacturer (Promega, Madison, WI, USA). After an alkaline-lysis extraction of the DNA, manual sequencing was performed following the dideoxynucleotide chain termination method (Sanger et al., 1977).

Sequence of alignments were made using CLUSTAL W (Thompson et al., 1994) with default settings (gap opening $=10$; gap extension $=0.05$ ). Adjustments to refine the alignments were made according to the secondary structure model of piranhas (Ortí et al., 1996). Segments were defined as stems and loops according to their base pairing and were folded to secondary structure by eye.

In order to assess the phylogenetic relationships between taxa, the data set was analysed with three methods of phylogenetic inference: maximum parsimony (Fitch, 1971), maximum likelihood (Kimura, 1980; Felsenstein, 1981) and neighbour joining (Saitou $\&$ Nei, 1987). Several weighting combinations were performed for transition (Ts)/transversion (Tv) (Ts/Tv $=1, \mathrm{Ts} / \mathrm{Tv}=1 / 2$ and $\mathrm{Ts} / \mathrm{Tv}=1 / 4)$ and stem $(\mathrm{St}) /$ loop $(\mathrm{Lp})(\mathrm{St} / \mathrm{Lp}=1, \mathrm{St} / \mathrm{Lp}=1 / 2$ and $\mathrm{St} / \mathrm{Lp}=1 / 4)$ to account 
Table 2. Morphometric and meristic variables used in this study. Marked (*) variables were not included in discriminant analysis. Except for TL and SL the remaining variables had zero variance in some fish groups

\begin{tabular}{ll}
\hline *Total length & $\mathrm{TL}$ \\
*Standard length & $\mathrm{SL}$ \\
Body depth & $\mathrm{Bd}$ \\
Head length & $\mathrm{Hl}$ \\
Head width & $\mathrm{Hw}$ \\
Sucking disc length & $\mathrm{SDl}$ \\
Sucking disc width & $\mathrm{SDw}$ \\
Secondary sucking disc length & $\mathrm{sSDl}$ \\
Secondary sucking disc width & $\mathrm{sSDw}$ \\
Distance between tip of snout and the anterior & $\mathrm{S}-\mathrm{D}$ \\
$\quad$ margin of the sucking disc & \\
Distance between the posterior margin of the & $\mathrm{SD}-\mathrm{A}$ \\
$\quad$ sucking disc and the anus & \\
Distance between the anus and the origin of & $\mathrm{A}-\mathrm{A}$ \\
$\quad$ the anal fin & \\
Dorsal fin length & $\mathrm{Dl}$ \\
Anal fin length & $\mathrm{Al}$ \\
Predorsal distance & $\mathrm{pD}$ \\
Preanal distance & $\mathrm{pA}$ \\
Caudal peduncle length & $\mathrm{CPl}$ \\
Caudal peduncle depth & $\mathrm{CPd}$ \\
Eye diameter (mean of left and right eye) & $\mathrm{Ey} \mathrm{d}$ \\
Inter-orbital distance & $\mathrm{Iod}$ \\
Pre-orbital distance (mean of left and right & $\mathrm{Pod}$ \\
$\quad$ preorbital distance) & \\
Length of posterior nostril's tentacle & $\mathrm{pNt}$ \\
Length of anterior nostril's tentacle & $\mathrm{aNt}$ \\
$\mathrm{N}^{\circ}$ of dorsal rays & $\mathrm{Dr}$ \\
$\mathrm{N}^{\circ}$ of papillae rows in anterior disc region & $\mathrm{papA}$ \\
$\mathrm{N}^{\circ}$ of papillae rows in posterior disc region & $\mathrm{papB}$ \\
* $\mathrm{N}^{\circ}$ of papillae rows in central disc region & $\mathrm{papC}$ \\
*Body colour pattern & $\mathrm{BP}$ \\
*Head ocelli & $\mathrm{HO}$ \\
\hline & \\
\hline
\end{tabular}

for the lack of independence among substitutions in stems. Neighbour joining results were obtained using Kimura 2-parameter distance. In order to identify the primitive characters, $L$. candolle $i$ was used as an outgroup. Analysis were performed with PAUP 4.0 beta 2 version (Swofford, 1997) and PHYLIP (Felsenstein, 1989).

Sequences were deposited in GenBank database and the accession numbers are: AY036587, AF388176 ( $L$. candollei); group 1: AY036599, AY036600, AY036601, AY036602, AY036603, AY036604, AY036605 (L. purpurea); group2: AY036589, AY036590, AY036591, AY036592, AY0 36593, AY036594; group 3: AY036598 (L. lepadogaster); group 4: AY036595, AY036596, AY036597 (L. zebrina).

\section{BREEDING SEASONS AND MICROHABITATS}

Ecology and reproduction of groups 1 and 2 were studied in the west coast of Portugal at Alpertuche, Arrábida $\left(38^{\circ} 28^{\prime} \mathrm{N}-8^{\circ} 59^{\prime} \mathrm{W}\right)$, with additional observations at Parede $\left(38^{\circ} 41^{\prime} \mathrm{N}-9^{\circ} 22^{\prime} \mathrm{W}\right)$. To determine the breeding season of each group, standard transects parallel to the shoreline were inspected monthly at low tide (from December 1998 to December 2000). Transects were $44 \mathrm{~m}$ long and $4 \mathrm{~m}$ wide. Up to 120 boulders and stones were inspected per transect and the presence of egg masses and fish, as well as their identity and size were recorded. After inspection, fish and stones were carefully placed as they where before. Similar observations were performed at Parede during the years 1993-94.

Some dives in the adjacent subtidal were performed and stones were lifted to check if the data obtained for the breeding season in the intertidal were also valid in subtidal conditions. The number of fish and the presence of egg masses were recorded.

To characterize the microhabitats of the two groups, data from transects inspected between January and August 2000 were used. The beach was divided in two zones (A and B) crossed by the transects and differing in the predominant type of stones. The stones were measured and the texture of their underside surface was qualitatively classified on a simple three-point scale: (1) smooth, (2) intermediate and (3) rough. The diversity of the biological cover was estimated based on the number of categories of benthic organisms that were attached. To avoid the effect of very rare organisms, only taxa that covered at least $10 \%$ of the underside of the stone were considered. The types of organisms found were: algae, sponges, cnidarians, bryozoans, annelids, barnacles, amphipods, decapods, gastropods, echinoderms, tunicates and fish. Fish abundance of each group was compared using Wilcoxon matched pairs test, and stone characteristics of the two zones were compared using ANOVA.

Phylogenetic analysis of morphological data was performed with the program 'CONTML' of the software package PHYLIP (Felsenstein, 1989). All other statistical treatments were performed with the software package STATISTICA 5.0 (C StatSoft, Inc).

\section{RESULTS}

The same pattern of relationship between groups was observed in all analysis (cluster analysis on morphological data, Figure 1; discriminant analysis for morphological data-Table 3; analysis of genetic data, Fig. 2; and genetic distance between groups, Table 4). After the separation of $L$. candollei specimens, two distinct groups emerged: one includes all specimens of group 1 , fish that would be classified as L. l. purpurea 


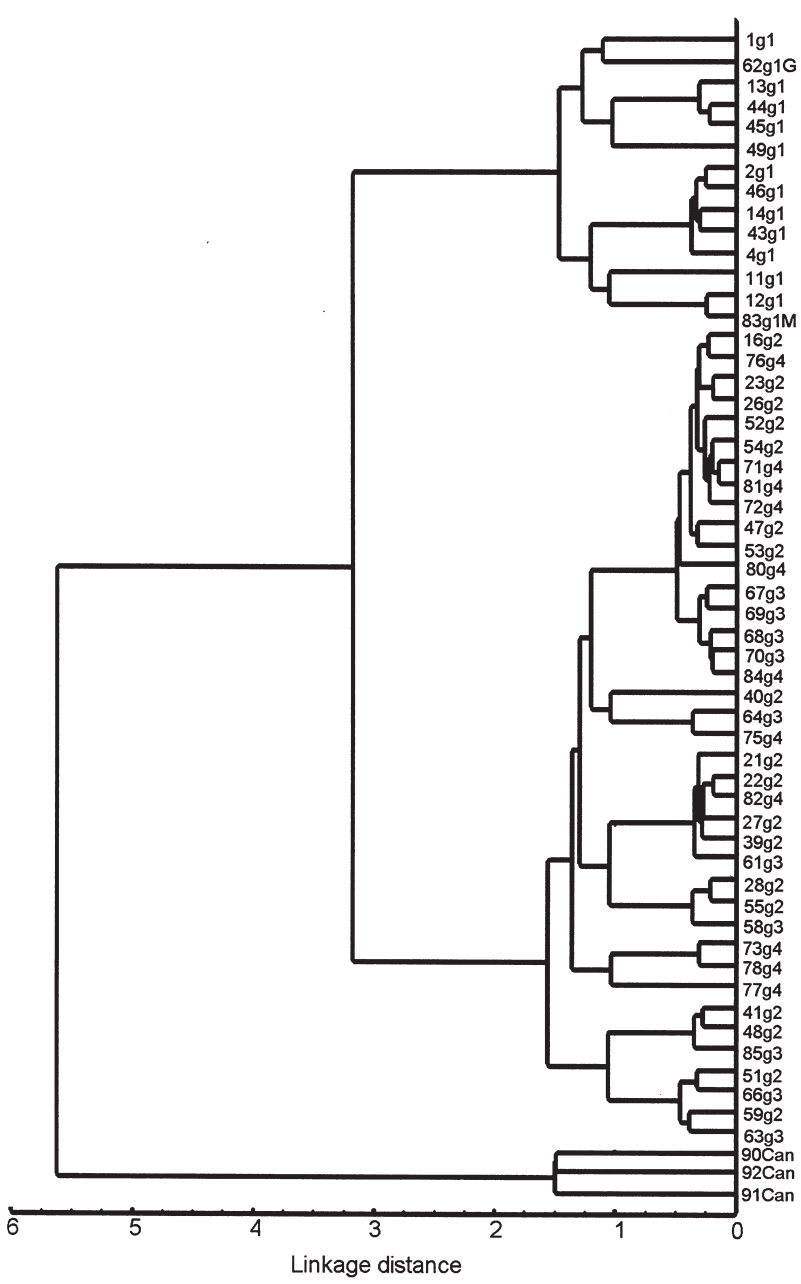

Figure 1. Cluster analysis based on the morphometric data, unweighted pair-group average with Euclidean distances. Each specimen are designated by it serial number plus the group considered (g1 to g4) or 'Can' for L. candollei specimens. Those of group 1 (L. l. purpurea) from Genoa and Madeira have the extra code G or M, respectively.

regardless of their geographical origin; the other includes the remaining fish (groups 2, 3 and 4). The only misclassification in the discriminant analysis was one specimen of L. zebrina that was classified as $L$. $l$. lepadogaster (group 3). The cladistic analysis of morphological data is not shown because basically it repeats the information already present in Figures 1 and 2: after the separation of $L$. candollei with a bootstrap of $100 \%$, all $L$. $l$. purpurea are separated from the remaining specimens with a bootstrap of $73 \%$; again, the specimens of groups 2, 3 and 4 did not form well differentiated entities.

This means that the specimens of L. zebrina (group 4) occur in the same cluster as all fish that could be classified as L. l. lepadogaster (groups 2 and 3). No recognizable subgroups were identified within this

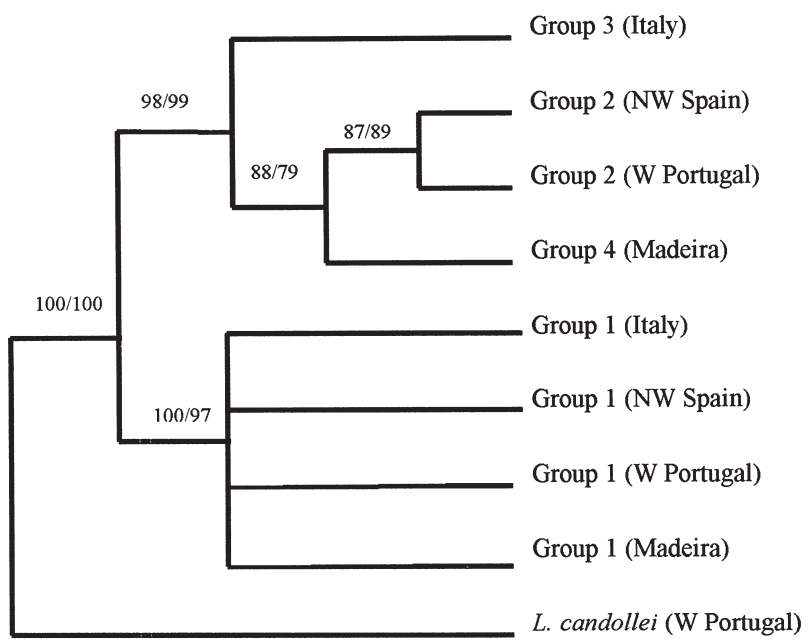

Figure 2. Phylogenetic tree obtained by maximum parsimony and neighbour joining analysis from the genetic data. Bootstrap values (parsimony/neighbour-joining) based on 1000 simulations are shown as percentages. Only values above $70 \%$ are presented in the tree.

cluster so the material from the Mediterranean, the Atlantic Iberian shores and Madeira cannot be distinguished. Additionally, the only specimen of group 1 ( $L$. purpurea) coming from Madeira and that from Italy are also mixed with the other members of their respective cluster. Thus, the two forms distinguished by these analysis are in sympatry at least from northwestern Spain to the Mediterranean coast of Italy and Madeira.

Partial sequences of the third domain of $12 \mathrm{~S}$ rDNA were folded into a secondary structure following the model of Ortí et al. (1996). Variation among sequences occurred mainly, although not exclusively, in loop regions. No transitional saturation was detected by plotting transitions and transversions vs. Kimura 2-parameter distances and all three methods of phylogenetic inference recovered the same topology, independently of the weighting schemes used for transitions/transversions and for stems/loops. The only gap opening in the DNA sequences alignment corresponded to the six specimens from group 2 and was one base-long. A total of 51 base differences (12.8\% of the DNA fragment sequenced) separated $L$. candollei from the ingroup (groups 1-4).

Genetic analysis revealed that L. zebrina could not be differentiated from the other fish since no synapomorphies were found for group 4. Group 1 (L. l. purpurea) is monophyletic the same being true for groups 2,3 and 4 combined (Fig. 2). Ten synapomorphies (2,3\% of the DNA fragment sequenced) separated L. $l$. purpurea from the clade $L$. l. lepadogaster/L. zebrina (groups 2, 3 and 4). L. zebrina is as distantly related 
Table 3. Standard discriminant analysis: Wilks' Lambda $0.001, F(96,113)=10.983, p<0.001 ; 55$ out of 56 fish were correctly classified. A, Mahalanobis distances (for all distances $\mathrm{p}<0.001$ ). B, Canonical variables. Cumulative proportion of the variance explained

\begin{tabular}{|c|c|c|c|c|}
\hline A- & purpurea(1) & lepadogaster(2) & lepadogaster(3) & zebrina $(4)$ \\
\hline purpurea(1) & - & & & \\
\hline lepadogaster(2) & 95.1 & - & & \\
\hline lepadogaster(3) & 97.3 & 24.6 & - & \\
\hline zebrina $(4)$ & 88.1 & 18.9 & 28.5 & - \\
\hline candollei & 1204.0 & 1411.8 & 1237.0 & 1327.0 \\
\hline B- & Root 1 & Root 2 & Root 3 & Root 4 \\
\hline Eigenval & 67.45 & 14.52 & 2.36 & 1.88 \\
\hline Cum. Prop. & 0.78 & 0.95 & 0.98 & 1.0 \\
\hline purpurea $(1)$ & -0.37 & 6.28 & 0.16 & -0.07 \\
\hline lepadogaster(2) & 3.53 & -2.01 & 0.49 & 1.51 \\
\hline lepadogaster(3) & 1.06 & -2.58 & 2.03 & -2.18 \\
\hline zebrina(4) & 2.33 & -1.74 & -2.66 & -0.90 \\
\hline candollei & -32.31 & -2.45 & -0.17 & 0.59 \\
\hline
\end{tabular}

Table 4. Kimura two-parameter genetic distance and mutation percentages between L. l. purpurea (group 1), L. l. lepadogaster (group 2-Atlantic populations, and group 3-Mediterranean population), L. zebrina (group 4) and the outgroup L. candollei

\begin{tabular}{|c|c|c|c|c|c|}
\hline Kimura-2 & purpurea(1) & lepadogaster(2) & lepadogaster(3) & zebrina(4) & candollei \\
\hline purpurea(1) & $0-0.01$ & - & - & - & - \\
\hline lepadogaster(2) & 0.04 & $0-0.003$ & - & - & - \\
\hline lepadogaster(3) & 0.03 & $0.008-0.01$ & 0 & - & - \\
\hline zebrina $(4)$ & $0.03-0.04$ & $0.005-0.01$ & $0.008-0.01$ & $0-0.003$ & - \\
\hline candollei & $0.16-0.17$ & $0.17-0.18$ & $0.16-0.17$ & 0.17 & $0-0.003$ \\
\hline$\%$ mutations & purpurea(1) & lepadogaster(2) & lepadogaster(3) & zebrina(4) & candollei \\
\hline purpurea(1) & $0-0.99$ & - & - & - & - \\
\hline lepadogaster(2) & $3.72-4.47$ & $0-0.25$ & - & - & - \\
\hline lepadogaster(3) & $2.73-3.23$ & $0.99-1.24$ & 0 & - & - \\
\hline zebrina $(4)$ & $3.23-3.97$ & $0.74-1.24$ & $0.74-0.99$ & $0-0.25$ & - \\
\hline candollei & $14.4-15.4$ & $14.89-16.13$ & 14.39-14.89 & 14.64-15.38 & $0-0.25$ \\
\hline
\end{tabular}

to L. l. lepadogaster (Kimura 2-parameter genetic distance 0.005-0.01) as are the Madeiran and continental populations of $L$. l. purpurea $(0.005-0.01)$ or $L$. candollei (0.005-0.008-GenBank accession number for Madeiran L. candollei AF388176). Finally, within the clade $L$. l. lepadogaster/L. zebrina the most divergent specimen was from the Italian population sample and not from the putative Madeiran species L. zebrina (Fig. 2).

In conclusion, both the genetic and morphological analysis point to a much greater separation between L. l. purpurea (group 1) and the combined L. l. lepadogaster (groups 2 and 3) + L. zebrina (group 4). These two new entities are however, more similar than any of them is to L. candollei.

Briggs (1955, 1986) mentioned body depth as the only morphometric character able to discriminate between $L$. zebrina and $L$. lepadogaster, being greater in the former. We could not confirm this difference. A comparison of the residuals after log-log regression BD/SL between group 4 (L. zebrina) and groups 1, 2 and 3 combined (the two subspecies of $L$. lepadogaster sensu Briggs) failed to detect any significant differences (rank sum: L. zebrina $=277, N=11$, L. lepadogaster $=1493, N=48 ; U=211, p=0.30$, Mann-Whitney $U$-test) and if anything, the value for 
Table 5. Descriptive statistics for morphometric (index over SL) and meristic variables for which there were significant differences at $p<0.01$. Wilks'Lambda $=0.096$, Rao's $(6,52)=81.18$, MANOVA test. Mean values are presented for the morphometric characters SDw, Iod and Pod, median values are presented for meristic papA, papB and Dr. *For anterior disc region (papA) L. lepadogaster presented only one over 42 specimens with five rows of papillae

\begin{tabular}{|c|c|c|c|c|c|c|c|}
\hline & & SDw & Iod & Pod & papA & papB & Dr \\
\hline \multirow[t]{4}{*}{ L. lepadogaster $n=42$} & Mean/median & 0.27 & 0.06 & 0.15 & 4 & 3 & 17 \\
\hline & Minimum & 0.23 & 0.05 & 0.13 & 3 & 3 & 16 \\
\hline & Maximum & 0.30 & 0.07 & 0.17 & $4\left(5^{*}\right)$ & 4 & 18 \\
\hline & $\mathrm{SD}$ & 0.018 & 0.005 & 0.009 & 0.5 & 0.4 & 0.6 \\
\hline \multirow[t]{4}{*}{ L. purpurea $n=17$} & Mean/median & 0.25 & 0.07 & 0.14 & 5 & 5 & 18 \\
\hline & Minimum & 0.22 & 0.06 & 0.12 & 5 & 5 & 18 \\
\hline & Maximum & 0.29 & 0.09 & 0.15 & 6 & 6 & 19 \\
\hline & $\mathrm{SD}$ & 0.018 & 0.008 & 0.012 & 0.5 & 0.5 & 0.5 \\
\hline
\end{tabular}

L. lepadogaster was slightly greater (median $\mathrm{BD} / \mathrm{SL}=$ 0.142 for L. zebrina and 0.149 for L. lepadogaster).

The small sample sizes did not allow a comparison of all morphometric variables in a single MANOVA test. To avoid retesting errors, a preliminary exploration of the residuals of the variables between $L$. $l$. purpurea and the remaining groups combined $(L$. zebrina $+L$. l. lepadogaster) were performed with the Mann-Whitney $U$-test. Only variables for which there were differences significant at $p<0.01$ were retained and subsequently used in a MANOVA. Although the MANOVA was performed on the residuals of the regressions between each morphometric characteristic and SL, the descriptive statistics for the indexes of these variables over SL are presented in Table 5, since these indexes are more informative than residuals.

In addition to the morphometric and meristic measures considered above, there was a consistent difference in head colour pattern between group 1 (L. purpurea) and the other groups (L. zebrina + L. lepadogaster). Fish of group 1 presented a pair of ocelli on the head behind the eyes, each with a central blue region surrounded by a brown ring. A blue oval line outlines each ocellus.

Fish of groups 2, 3 and 4 have a single blue line over the head that is not divided in two ocelli, although a central constriction varying in prominence is present. This crescent shape area, together with the white lines that run between the eyes in all fish, are in the origin of the so-called 'brown crescents' of the old descriptions found in the literature for some fish (e.g. Lacépède, 1800). Although two small blue marks may be present, they never show the well define round shapes and are not surrounded by the brown rings (see Fig. 3).

Body colour pattern is more variable. It is formed by light brown or purple spots in $L$. $l$. purpurea while in the Atlantic specimens of $L$. l. lepadogaster and $L$. zebrina there are dark vertical oval shapes that in many individuals are so stretched in length that they became vertical dark bands on the sides with dots on the back. However, in L. l. lepadogaster specimens from the Mediterranean, only dark spotting was observed.

\section{BREEDING SEASONS AND MICROHABITATS}

In continental Portugal, group 1 males (L. purpurea) were found guarding eggs from November 1998 to April 1999, starting one month earlier in the adjacent subtidal habitat, and from October 1999 to the end of March 2000 with no differences between intertidal and subtidal habitats. Group 2 males (L. lepadogaster) were found guarding eggs from March to June in 1999 and from March to the end of July in 2000, both in intertidal and subtidal habitats. Thus, the period where the two forms are found breeding simultaneously is very short with most of their breeding seasons out of phase. L. candollei was found guarding eggs from March to late August mainly in subtidal habitat.

Concerning the microhabitat of the two forms it was found that the two sections of the beach (see Methods) differed consistently in their use by the fish. Group 1 (L. purpurea) was more abundant in section $\mathrm{A}(\mathrm{Z}=$ 3.18, $n=13, p<0.001$, Wilcoxon matched pairs test) and Group 2 (L. lepadogaster) was more abundant in section $B(Z=3.18, n=13, p<0.001$, Wilcoxon matched pairs test).

With regard to boulder characteristics, there were significant differences between the two sections (Wilks' Lambda 0.36, Rao'R $(3420)=254.42, p<0.001$, MANOVA test). Stones in section A are larger (mean area $661 \mathrm{~cm}^{2}$ ) than in section B (mean area $\left.477 \mathrm{~cm}^{2}\right)$. Diversity and roughness of the underside surface decreased from section A to $\mathrm{B}$ (mean diversity $=2.99$ 


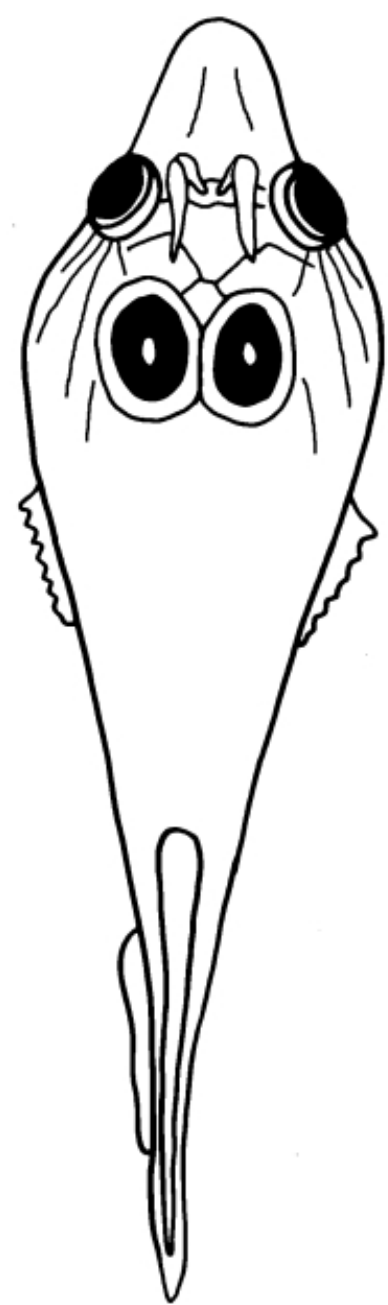

A

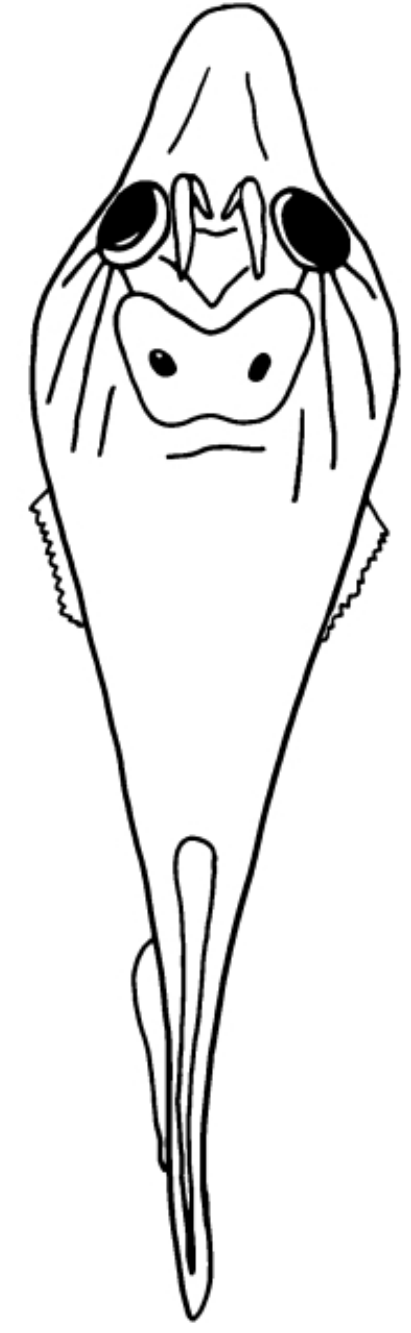

B
Figure 3. Head marks: A, L. purpurea; B, L. lepadogaster.

groups of organisms for section A and 1.58 for section $\mathrm{B}$ and mean roughness index $=2.69$ for section $\mathrm{A}$ and 1.27 for section $\mathrm{B})$.

Throughout the study period, regular diving at these sites indicated that both forms were found in the subtidal down to $7 \mathrm{~m}$ depth which is the lower limit of the stony habitat at the study area. Apparently, both forms continue to prefer different types of stones in the subtidal, with preferences similar to those found in the intertidal. No depth segregations could be detected.

\section{DISCUSSION}

The results of this study may be summarized as follows: both morphological and molecular comparisons indicate that L. zebrina is not more distinct from the populations of $L$. l. lepadogaster than these are among themselves. In contrast, L. l. purpurea emerged in all analysis as a distinct entity. L. candollei is strongly divergent from a monophyletic group, that in turn splits in two cohesive subgroups. These subgroups are sympatric from north-west Spain to the Mediterranean and Madeira island, their breeding seasons are out of phase and they differ in microhabitat choice. Examination of material belonging to the Oceanographic Museum of Arrábida Nature Park (Portugal) collected in 1905 in the study area, revealed that the two forms were already sympatric on the Portuguese shore at that time.

These findings lead us to conclude that we are in the presence of two valid species: one including the fish that traditionally were ascribed to $L$. $l$. purpurea (group 1) and another including the fish of groups 2, 3 and 4 , traditionally ascribed to L. zebrina and L. l. lepadogaster. With the available evidence, we think that it is more parsimonious to consider two species (L. purpurea and L. lepadogaster) than to raise to specific status all subgroups that could be detected. It is important to stress again that the difference pointed by Briggs $(1955,1986)$ as the distinctive criterion to separate L. zebrina and L. l. lepadogaster was not supported by our results. Indeed, L. zebrina is as distantly related to $L$. lepadogaster as are the Madeiran populations of $L$. purpurea and $L$. candollei from their respective continental counterparts. According to the priority principle of the zoological nomenclature, the first species must be called L. purpurea (Bonnaterre, 1788), and the second L. lepadogaster (Bonnaterre, 1788). Indeed, this author was the first to use these names for fish caught in England and in the Mediterranean, respectively. His drawings and descriptions clearly correspond to the two species proposed in our study. A list of distinctive characters and a summary of synonyms, are presented in appendices A and B.

Because of the general loss of type material and the vast sympatry of these two species, one neotype for each species will be deposited at the Muséum Nationale d'Histoire Naturelle, Paris, with MNHN numbers: 2001-1240 (L. lepadogaster) and 2001-1241 (L. purpurea).

L. purpurea now has the following distribution: from Scotland to Senegal, the Canary islands and Madeira islands and the Mediterranean, at least as far east as Genoa (Italy). The distribution of L. lepadogaster ranges at least as far north as the extreme north-west of Galiza, south to north-west Africa, the Canary islands and Madeira islands and also the Mediterranean. The Black Sea specimens could belong to either species according to the work of Murgoci (1964) who identified in that region the purpurea subspecies described by Briggs (1986, 1990). Finally, the population from Morocco, that Brownell (1978) found to have intermediate distribution of meristic counts, could in fact contain specimens from both species. 
It may seem hard to explain how such an extensive sympatry between $L$. purpurea and $L$. lepadogaster could go unnoticed for such a long period. In our view, it is likely that the explanation lie in the cryptic behaviour of these fish. They are very small and stay almost always under boulders, which makes them very hard to detect in conventional ichthyofaunal surveys. As L. purpurea is associated with boulders that are of an unusually large size, rare in most shores, this species is still more easily overlooked. In scuba surveys at Madeira (Funchal) and southern France (Cape Roux), where only the type of stones preferred by $L$. lepadogaster was available, only this species was collected. In addition, variation in trunk colour pattern between populations of $L$. lepadogaster made the situation more difficult to clarify.

There is no calibration available to use the rate of divergence of the DNA fragment studied as the basis for a molecular clock in gobiesocid evolution. Estimates of base substitution rate in mitochondrial DNA in ectotherms and for a variety of mitochondrial genes, usually range from 1 to $2 \%$ substitutions per million years (myr) (Avise, 1994). The percentage of divergence between $L$. lepadogaster and $L$. purpurea in our study ranged from $2.73 \%$ to $4.47 \%$, as shown in Table 4. Assuming that the figures for base substitution rates are applicable to this group and to the specific fragment of DNA analysed, the higher values would point to a divergence time of more than 1 myr. Using the most conservative estimates the divergence time would point to more than 4 myr. This observation means that the speciation event that separated $L$. lepadogaster from $L$. purpurea is probably not a recent event and may have occurred prior to the beginning of the Pleistocene. The divergence of about $1 \%$ between haplotypes from populations of each species provide additional evidence in favour of a pre-Pleistocenic timing for the speciation event that separated the two species. The large extent of their sympatry is also suggestive of a considerable long history as separate species.

L. lepadogaster and L. purpurea are very similar in morphology and both are cryptic species that breed, feed and hide under boulders. However, they select boulders of very different sizes which means that it is unlikely that they actually compete for breeding or shelter sites. The large boulders inhabited by $L$. purpurea harbour a much higher diversity of organisms and form the basis of a more stable community. Thus, we suggest that the two species, although sympatric in most of their range, must display low levels of interspecific competition.

L. candollei emerged in all analysis as very distinct from the monophyletic group formed by $L$. lepadogaster and $L$. purpurea. The percentage of divergence between $L$. candollei and the two other species ranged from 14.39 to $16.13 \%$. These values point to a Miocenic timing for their separation likely prior to the Messinian crisis that affected the Mediterranean at about 5.5 myr (Briggs, 1995). L. candollei is also very distinct from the other species both in morphology and behaviour (Gonçalves et al., 1998). It is an active swimmer that feeds out of shelter and often preys the nests of other fish species (Almada et al., 1987). The disparity in divergence times, and all differences mentioned above between $L$. candollei and the other two Lepadogaster species, raise doubts about the inclusion of these species in the same genus. Further phylogenetic analysis of Lepadogastrin gobiesocids, including a broader spectrum of genera and species, is required to clarify their relationships.

Finally, we would like to mention that, previous works from some of the authors of the present paper (Gonçalves et al., 1996, 1998), supposedly dealing with L. l. purpurea are, in the light of the present findings, studies on $L$. lepadogaster.

\section{ACKNOWLEDGEMENTS}

The authors would like to thank to Estação de Biologia Marinha do Funchal and its team for field and logistic help during work on Madeira island, and to Dr Riccardo Cattaneo-Vietti, Simone Bava and Stefano Schiaparelli for collecting fish from Genoa. We also thank Emanuel Gonçalves, John C. Briggs and an anonymous referee for their helpful review comments. This study was partially supported by Fundação para a Ciência e Tecnologia (FCT) through the project PRAXIS/3/3.2/EMG/1957/95, the fellowships GGPXXI/ BIC/3570/96 (to R.L); PRAXIS XXI/BPD4470/96 (to T.G); PRAXIS XXI/BD/11178/97 (to F.A) and through the Pluriannual Program (UI \& D 331/94).

\section{REFERENCES}

Albuquerque RM. 1954-56. Peixes de Portugal e Ilhas adjacentes. Chaves para a sua determinação. Portugaliae Acta Biologica Sér. B 5: 1040-1041.

Almada VC, Garcia G, Santos RS. 1987. Padrões de actividade e estrutura dos territórios dos machos parentais de Parablennius pilicornis Cuvier (Pisces: Blenniidae) da costa portuguesa. Análise Psicológica 2: 261-280.

Avise JC. 1994. Molecular Markers, Natural History and Evolution. New York: Chapman \& Hall.

Bloch ME, Schneider JG. 1801. M. E. Blochii Systema Ichthyologiae iconibus cx illustratum. Post obitum auctoris opus inchoatum absolvit, correxit, interpolavit. Saxo, Berolini: Schneider JG.

Bonnaterre JP. 1788. Ichthyologie. Tableau encyclopédique et méthodique des trois règnes de la Natura. Paris. 
Briggs JC. 1955. A Monograph of the Clingfish (Order Xenopterygii). Stanford Ichthyological Bulletin 6: 3339.

Briggs JC. 1957. A new genus and two new species of eastern Atlantic clingfish. Copeia 1957: 204-208.

Briggs JC. 1986. Gobiesocidae. In: Whitehead PJP, Bauchot M-L, Hureau J-C, Nielson J, Tortonese E, eds. Fish of the North-Eastern Atlantic and the Mediterranean. Paris: UNESCO, 1351-1359.

Briggs JC. 1990. Gobiesocidae. In: Quéro JC, Hureau JC, Karrer C, Post A, Saldanha L, eds. Check-List of the Fish of the Eastern Tropical Atlantic. Lisboa, Portugal: UNESCO, SEI, JNICT, 476-478.

Briggs JC. 1995. Global Biogeography. Amsterdam: Elsevier.

Brito A. 1982. Contribution al conocimiento de la fauna ictiologica de las Islas Canarias: Sobre las especies del Genero Lepadogaster Gouan, 1770 (Pisces: Gobiesocidae). Vieraea 11: 193-206.

Brownell C. 1978. Sur quelques collections de poissons littoraux de L'Atlantique Marocain. Bulletin Institut Pêches Maritimes, Casablanca 23: 111-133.

Canestrini G. 1864. Studi sui Lepadogaster del Mediterraneo. Archives de Zoologie, Anatomie et Fisiologie 3: 177196.

Couch J. 1877. History of the Fish of the British Islands. London: George Bell \& Sons.

Donovan E. 1806. The natural history of British fish including scientific and general descriptions of the most interesting species, and an extensive selection of accurately finished coloured plates, taken entirely from original drawings, purposely made from the specimens in a recent state, and for the most part whilst living. London.

Felsenstein J. 1981. Evolutionary trees from DNA sequences: a maximum likelihood approach. Journal of Molecular Evolution 17: 368-376.

Felsenstein J. 1989. PHYLIP - Phylogeny Inference Package Version 3.2. Cladistics 5: 164-166.

Fitch WF. 1971. Toward defining the course of evolution: minimum change for a specified tree topology. Systematic Zoology 20: 406-416.

Fleming J. 1828. A history of British animals exhibiting the descriptive characters and systematical arrangements of the genera and species of quadrupeds, birds, reptiles, fish, mollusca and radiata of the U.K. including the indigenous, extirpated and extinct kinds, together with periodical and occasional visitants. Edinburgh.

Fowler HW. 1936. The Marine Fish of West Africa, based on the collection of the American Museum Congo Expedition 1909-15. Bulletin of the American Museum of Natural History 70: 1080-1081. fig. 453.

Gonçalves EJ, Almada VC, Almeida SP, Gonçalves DM, Repas M, Simões N. 1996. Observations on the behaviour of Lepadogaster lepadogaster purpurea (Pisces: Gobiesocidae). Journal of Fish Biology 49: 367-369.

Gonçalves DM, Gonçalves EJ, Almada VC, Almeida SP. 1998. Comparative behaviour of two species of Lepadogaster (Pisces: Gobiesocidae) living at different depths. Journal of Fish Biology 53: 447-450.
Guitel F. 1888. Recherches sur les Lepadogasters. Archives de Zoologie expérimentale et générale 2e. Série 6: 545-548, pl. XXIX.

Günther A. 1861. Catalogue of the Acanthopterygian Fish in the Collection of the. British Museum, Gobiidae, Discoboli, Pediculati, Blenniidae, Labyrinthici, Mugilidae, Notacanthi. London.

Hofrichter R. 1995. Taxonomie, Verbreitung und Okologie von Schildfichen der Unterfamilie Lepadogastrinae (Gobiesocidae, Teleostei). PhD Thesis, University of Salzburg.

Horai S, Hayasaka K, Kondo R, Tsugane K, Takahata N. 1995. Recent African origin of modern humans revealed by complete sequences of hominoid mitochondrial DNAs. Proceedings of the National Academy of Sciences USA 92: 532536.

Jenkins JT. 1936. The Fish of the British Isles Both Fresh Water and Salt. 2nd edn. London: Warne.

Kimura M. 1980. A simple method for estimating evolutionary rates of base substitutions through comparative studies of nucleotide sequences. Journal of Molecular Evolution 16: 111-120.

Lacépède B. 1800. Histoire naturelle des Poissons. Paris. Lacépède B. 1831. Histoire naturelle des Poissons. Paris.

Le Danois E. 1913. Contribution à l'étude systématiques et biologique des poissons de la manche occidentale. Annales de L’insitute Océanographique, Monaco 5: 126.

Lowe RT. 1839. A supplement to a synopsis of the fish of Madeira. Proceedings of the Zoological Society of London 7: $76-92$.

Lozano y Rey L. 1960. Peces fisodistos. Tercera parte. Subseries Toracicos (Ordenes Equeneiformes y Gobiformes), Pediculados y Asimetricos. Memorias de la Real Academia de Ciencias Exactas. Fisiológicas Y Naturales de Madrid (Series Cienc Nat) 14: 294-295.

Maniatis T, Fritsch EF, Sambrook J. 1982. Molecular Cloning: a Laboratory Manual. New York: Cold Spring Harbor Press.

Murgoci AA. 1964. Contribution à la connaissance des gobiesocides (ordre des Xenopterygii) de la mer Noire. Revue Roumaine de Biologie, Série de Zoologie 9: 297-306.

Ninni AP. 1933. Primo contributo allo studio dei 'Lepadogaster'. Notas Y Resumes Instituto Españological de Oceonografia 65: 1-34.

Ortí G, Petry P, Porto JIR, Jégu M, Meyer A. 1996. Patterns of nucleotid change in mitochondrial ribosomal RNA genes and the phylogeny of piranhas. Journal of Molecular Evolution 42: 169-182.

Rafinesque-Schmaltz CS. 1810. Caratteri di alcuni nuovi generi e nuove specie di animali (principalmente di pesci) $e$ piante della Sicilia, con varie osservazioni sopra $i$ medisimi. Palermo.

Risso A. 1810. Ichthyologie de Nice, ou histoire naturelle des poissons du département des Alpes Maritimes. Paris.

Risso A. 1826. Histoire naturelle des principales productions de l'Europe méridionale et particulièrement de celles des environs de Nice et des Alpes maritimes. Paris \& Strasbourg.

Russel FS. 1976. The Eggs and Planktonic Stages of British Marine Fish. London: Academic Press. 
Saitou N, Nei M. 1987. The neighbour-joining method: a new method for reconstructing phylogenetic trees. Molecular Biology and Evolution 4: 406-425.

Sanger F, Nicklen S, Coulson AR. 1977. DNA sequencing with chain terminator inhibitors. Proceedings of the National Academy of Sciences USA 74: 5436-5437.

Shaw G. 1804. General zoology or systematic natural history. London.

Soljan T. 1948. Fauna I Flora Jadrana. Zagreb: Hrvatske.

Swofford DL. 1997. PAUP - Phylogenetic Analysis Using
Parsimony Version 4.0. Sunderland, MA: Sinauer Associates.

Thompson JD, Higgins DG, Gibson TJ. 1994. CLUSTAL $\mathrm{W}$ : improving the sensitivity of progressive multiple sequence alignment through sequence weighting, positionspecific gap penalties and weight matrix choice. Nucleic Acids Research 22: 4673-4680.

Wheeler A. 1969. The Fish of the British Isles and Northwest Europe. London: Macmillan.

Yarrell W. 1836. A History of British Fish. London.

Yonge CM. 1949. The Sea Shore. London: Collins.

\section{APPENDIX A}

Characters used to distinguish the two species of Lepadogaster. The distinction of the two species using live animals may be based on:

1 Head marks-Two ocelli in L. purpurea and one large crescent shape in L. lepadogaster (Fig. 3).

2 Papillae of sucking disc region A-5/6 rows in $L$. purpurea and 3/4 rows in L. lepadogaster (Fig. 4). We found one $L$. lepadogaster over 49 with 5 rows in this region.

3 Papillae of sucking disc region $\mathrm{B}-5 / 6$ rows in $L$. purpurea and $3 / 4$ rows in L. lepadogaster, being the papillae larger in the later species (Fig. 4).

4 At least out of the Mediterranean, the two species also clearly differ in body colouration pattern: spotted in $L$. purpurea and vertically striped in $L$. lepadogaster.
5 When seen side-by-side, it is clear that L. purpurea has a shorter nose and eyes much more separated (Fig. 3),

When dead fish are preserved items 1 and 4 rapidly became useless. Criteria 2, 3 and 5 can be used but the papillae of the sucking disc tend to be lost and even their insertion marks on the disc are not always apparent. In these cases, identification could be based on the size of the individual papillae: those of $L$. purpurea are more numerous but smaller in size than those of L. lepadogaster (see Fig. 4). Papillae of sucking disc region $\mathrm{C}$ could be in some cases useful: $5 / 4$ rows in $L$. purpurea and $4 / 3$ rows in $L$. lepadogaster. The same applies to the dorsal fin rays: $18 / 19$ rays in $L$. purpurea and $16 / 18$ rays in L. lepadogaster.

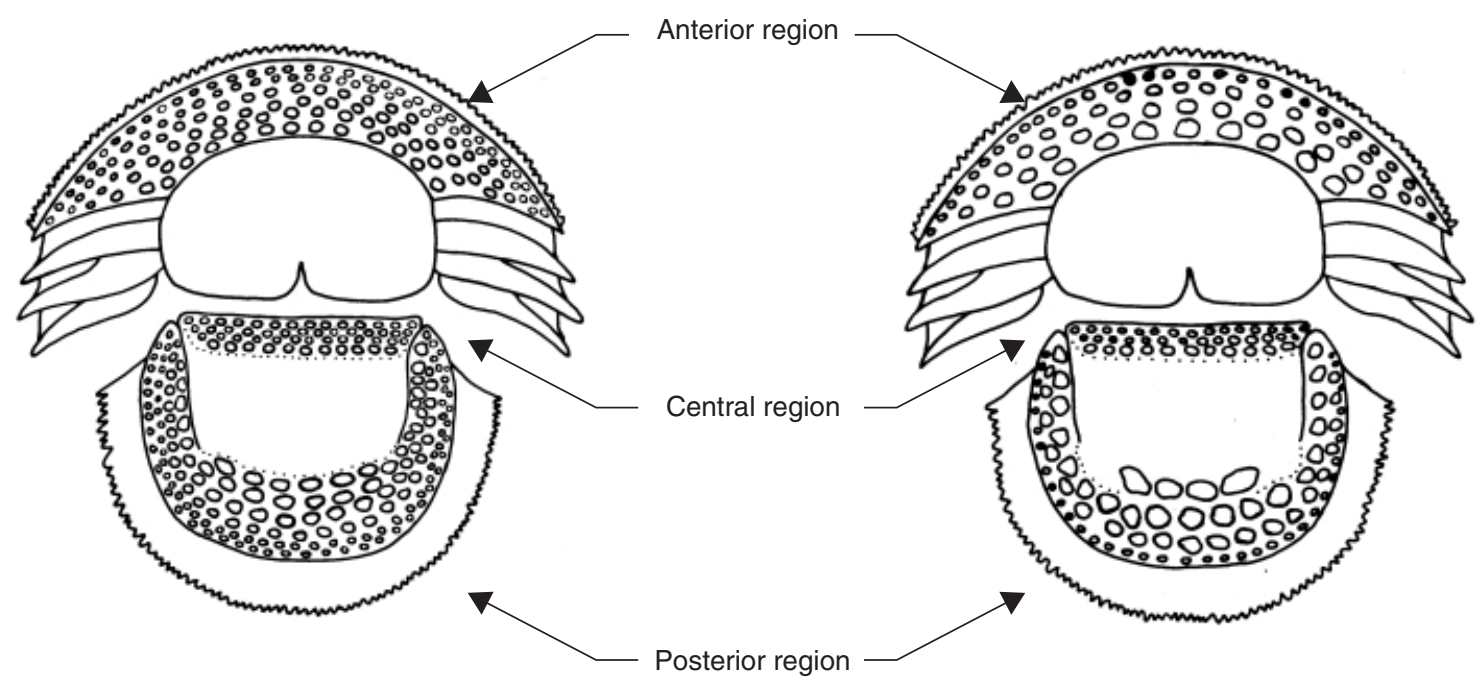

A

Figure 4. Sucking disc with rows of papillae: A, L. purpurea; B, L. Lepadogaster. 


\section{APPENDIX B - SYNONYMS}

Although many designations are too vague to be ascribed with certainty to any of the two species, we present below a list of the synonyms that correspond unambiguously to each species, based on our own survey of the primary literature. We must mention that, contrary to Briggs (1986, 1990), L. balbis and L. biciliatus were found to be synonyms of $L$. purpurea based on the original descriptions of the head colour patterns.

Lepadogaster purpurea (Bonnaterre, 1788)

Cyclopterus purpureus Bonnaterre (1788) (British Isles).

Lepadogaster rostratus Bloch \& Schnider (1801) (British Isles).

Cyclopterus cornubicus Shaw (1804) (British Isles).

Cyclopterus ocellatus Donovan (1806) (British Isles).

Lepadogaster balbis Risso (1810) (France, Mediterranean)

Lepadogaster biciliatus Risso (1826) (France, Mediterranean); Ninni, 1933 (Italy)

Lepadogaster cornubiensis Fleming (1828) (British Isles); Yarrel, 1836 (British Isles).

Cyclopterus spatulata Lacépède (1831) (British Isles).

Lepadogaster gouanii Couch (1877) (British Isles); Guitel, 1888 (Roscoff, France); Jenkins, 1936 (British Isles); Yonge, 1949 (British Isles).
Lepadogaster lepadogaster Fowler (1936) (Canaries); Wheeler, 1969 (British Isles); Russel, 1976 (British Isles).

Lepadogaster lepadogaster purpurea Briggs (1955), (1957), (1986), (1990) (Scotland to Dakar, Canaries, Madeira, western Mediterranean); Murgoci, 1964 (Black Sea); Brito, 1982 (Canaries).

Lepadogaster lepadogaster (Bonnaterre, 1788)

Cyclopterus lepadogaster Bonnaterre

(1788) (Mediterranean).

Lepadogaster gouanii Lacépède (1800) (Mediterranean); Risso, 1810, 1826 (France, Mediterranean); Canestrini, 1864 (Italy); Ninni, 1933 (Italy); Soldjan, 1948 (Adriatic, Italy).

Pischephalus adherens Rafinesque-Schmaltz (1810) (Sicily, Italy).

Lepadogaster brownii Risso (1826) (France, Mediterranean); Canestrini, 1864 (Italy); Ninni, 1933 (Italy); Soldjan, 1948 (Adriatic, Italy).

Lepadogaster zebrinus Lowe (1839) (Madeira)

Lepadogaster acutus Canestrini (1864) (Italy); Ninni, 1933 (Italy).

Lepadogaster zebrina Briggs (1955), (1986), (1990) (Madeira, Canaries); Brito, 1982 (Canaries).

Lepadogaster lepadogaster lepadogaster Briggs (1955), (1957), (1986) (eastern Mediterranean). 